somebody designs a new delivery system, should not be weapons laboratories be asked to tailor the ideal warhead to it? The weapons laboratories answer enthusiastically and affirmatively. The truth, however, is that both the superpowers must now have such a range of efficient warheads that the search for perfection cannot substantially affect national security. Third, more important but less tangible, the military (on each side) would be psychologically uneasy (and the weapons laboratories would lose some of their best people) if testing were prevented by means of a comprehensive test-ban treaty. The strength of this objection was consistently underestimated in President Carter's unrealistic times. The result is that too little has been done, in the United States and elsewhere, to prepare the military for living without tests. It would be too much to hope that Mr Weinberger will take on this task so early in his career at the Pentagon. The best hope now is that the pressure of events will persuade him or his colleagues of the importance of the exercise.

For the immediate future, then, the prospect for substantial progress in arms control is far from bright. The new Administration will find itself dragged reluctantly towards Salt III. The Comprehensive Test-Ban Treaty will hang fire until opinion changes towards the second half of Mr Reagan's term. Wrongly, the Reagan Administration will be pilloried when it sets about the dismantling of President Carter's clumsy antiproliferation apparatus and may even be persuaded as a result that it had better stay clear of anything to do with arms control. That would be a great misfortune, especially because the agenda the Administration has inherited includes two treaties whose ratification by the United States Senate would bring benefits that are totally unalloyed. The Threshold Test-Ban Treaty (limiting tests to the equivalent of 150,000 tonnes of TNT of explosive power) includes provision for the definition of allowed testing sites, and for the pre-arranged calibration of the seismic characteristics of the underlying rocks, that would immediately improve the efficiency of the seismic detection networks on both sides. The treaty to regulate the use of peaceful nuclear explosions (with which even the Soviet Union now seems disenchanted) provides for similarly open exchanges of technical data about the characteristics of nuclear explosions. Would it not make sense, even for an administration anxious to demonstrate its firmness with the Soviet Union, to ratify (with the assistance of the Senate) these treaties? For as things are, the United States government (like that of the Soviet Union) dares not break the rules agreed, but cannot enjoy the benefits that would accrue from ratifying the treaties. Even Mr Reagan and his colleagues must know that that is absurd.

\title{
Can British education be reformed?
}

The British educational system, long and widely known for its waywardness (the encouragement of school students to abandon those studies of which they are most in need) and excesses (the preoccupation with examinations), may be about to change. The government has now published a document, The School Curriculum, that sets out a recipe for a uniform and rational curriculum for British schools and which also promises (some teachers say "threatens") a continuing interest in progress towards its modest goals. Others than the British may not fully appreciate the momentous and historic significance of what the British government has done. Although the education of the young is financed largely from taxation, the central government has no constitutional right to intervene in what is taught in British schools. The only legislative constraint on the school curriculum, embodied in the Education Act of 1944, is that publicly supported schools must provide religious instruction of some kind. For the rest, local educational authorities are constitutionally the final arbiters of the curriculum, but it has never been finally decided whether even they can tell head teachers how the school curriculum should be designed. Indeed, head teachers themselves are frequently at loggerheads with teachers and teachers' unions because their power to decide what should be taught in their schools is circumscribed by teachers' insistence on "academic freedom". Throughout the 1960 s, when schools were sufficiently well supplied with funds to be able to experiment with the curriculum, successive central governments justified their cowardly detachment from what has happened by saying that they had no authority to intervene. It is therefore all the more creditable that central government should have chosen to intervene at this point, when there are no substantial funds with which to grease the palms of recalcitrant education authorities.

It remains to be seen how effective the new interventionist regime will be. The School Curriculum has only one important argument - that there should be a core curriculum in all publicly supported schools, consisting of language (usually English language), mathematics and science, and that no student in a secondary school should be allowed (let alone encouraged) to give up such a study before the age of 16 . In addition, the document says, students in secondary schools "should undertake some study of the humanities designed to yield lasting benefit"'. The document recites predictable platitudes about the importance of moral education, preparation for adulthood and the like, and is intelligent but also defeatist about foreign language learning. Must not such a moderate and modest programme of reform

\section{surely succeed?}

Unfortunately, the outcome is by no means assured. Schools and the teachers' unions have been quick to say that the government cannot will the ends without providing the means and that there is not merely a shortage of money but of people. For decades, the British educational system has been crippled by the lack of confident teachers of the essential parts of the curriculum as now defined - science, mathematics and modern languages. Even in first language teaching, trendily dubbed "communication skills" by too many schools, the efforts of able teachers are too often of fset by those of teachers who believe that any string of words is a measure of a student's creativity, and therefore to be valued. The British government must know that even its modest proposals will not have the influence expected of them unless it can arrange for a general improvement in the quality of teaching. But recruiting more specialists, people with good degrees in mathematics, physics or even French, is no solution. A degree in mathematics is no assurance that a person will be able to explain the working of a slide-rule to a class of 12-year-olds. Nor will similar qualifications in other fields help primary school teachers to persuade even younger children that they are genuinely teachers.

Having embarked on the courageous course of pretending to have an opinion on the school curriculum, the British government has in the process saddled itself with an administrative problem. How will it enable the schools, at least some of which are eager to follow the instructions now implicitly handed down, to do what is asked of them? The most immediate need is not (as the teachers' unions and many schools have been saying) to increase the supply of specialist teachers but to rid the schools system of the tyranny of the public examinations that now dominate the curriculum. Fortunately, having agreed that there should be a reorganization of the public examinations provided for 16-year-olds, the government is well placed to do just this. The ideal would be that it should let schoois (or their education authorities) provide schoolleavers with suitable certificates and that the public examinations for 18-year-olds, the most distorting of present influences on the school curriculum because of their use as means of selecting students for higher education, should be abolished. Then, paradoxically, the government would find that, having made its point about the pattern of education, it could confidently allow schools to get on with the only task for which they are equipped teaching young people. Left to themselves, but with clear objectives, they would find the teachers that they need. 